\title{
CORRESPONDENCE
}

\author{
THE GREAT GLEN CRUSH BELT
}

SiR,-I am pleased that my little paper on "Mylonite, Slickensides, and the Great Glen Fault " (Geol. Mag., 1951, p. 423) has had the desired effect of drawing from Messrs. Eyles and MacGregor some hitherto unpublished data bearing on the structure of that region. My intention, in writing that paper, was to demonstrate the inadequacy of the evidence relating to mylonite which Kennedy advanced in support of his conclusion that " the predominant displacement along the Great Glen Fault was horizontal" rather than vertical, as Horne and others had supposed. The new evidence is valuable in itself, but it does not help us to distinguish between these possibilities because mylonite may be generated by movement in either direction. As I wrote in my paper, "It is not enough to say that mylonite has been found " without trying to determine the direction of movement, which is the only thing that matters. Elsewhere in my paper I said that the evidence about Loch Oich and Loch Lochy "suggests collapse of the sandstone into a fault-trough". Is there anything in the new evidence to dispose of that possibility ?

If Eyles and MacGregor will read Kennedy's paper more carefully, they will see that he referred to a zone of crushed rocks within the Glen, because he wrote "Most of this zone is concealed by the deep superficial deposits of the Glen or the waters of the lochs ". My comment on the scarcity of mylonite in this zone is not invalidated by discoveries made beyond the bounds of the Glen.

\section{UNIVERSITY CLUB,}

S. J. SHAND.

EDINBURGH.

6th December, 1952.

\section{“ASSOCIATION POUR L'ÉTUDE GÉLLOGIQUE DES ZONES PROFONDES DE L'ÉCORCE TERRESTRE"}

SIR,--May I bring the following matter to the notice of your readers :-

During the course of the 19th Geological Congress held in Algiers during last September, it was proposed that there should be formed an "Association for the Geological Study of the Deep Zones of the Earth's Crust ". A provisional committee was formed comprising-

Prof. P. Michot, Université de Liége.

Prof. E. Raguin, Ecole des Mines, Paris.

Prof. M. Roques, Université de Clermont-Ferrand.

Prof. E. Wegmann, Université de Neuchatel.

Prof. J. G. C. Anderson, University College, Cardiff.

It should be explained that it is not the aim of the proposed Association to study the deeply-buried parts of the earth's crust by geophysical methods, but to investigate rocks formed by deep-seated processes and now exposed. For the present, at any rate, the main function of the Association would be to arrange excursions, under the leadership of one or more members, to districts where such rocks may be readily studied by normal geological methods.

At Algiers about fifty geologists signified their willingness to join such an Association. Other geologists who wish to join are invited to send their names and addresses either directly to Prof. M. Michot, Université de Liége, Belgium, or through the undersigned.

\section{UNIVERSITY COLLEGE, NEWPORT ROAD, CARDIFF.}

18th December, 1952.

\section{J. G. C. Anderson.}

